ARTICLE

https://doi.org/10.1057/s41599-020-0431-6

\title{
Smallpox inoculation: translation, transference and transformation
}

Anne Eriksen ${ }^{1 凶}$

\begin{abstract}
In the early decades of the eighteenth century, small pox inoculation was introduced into northern Europe from the Middle East. The method consisted of grafting infected matter from a person who suffered from smallpox into the arm of one who had not yet been attacked by the disease. The operation usually caused a mild case of illness and protected against further attacks. A series of translations and transformations was involved in the introduction of this new medical treatment. Linguistic and other translational shifts took place. The present article investigates four texts that introduced the new practice to readers in northern Europe, all published in London in the period 1714-1722. Starting out from the general point that translation always will create something new, the article develops the notion of translational bridges: to get the message through, the translator must employ devices or 'dispositifs' that connect the source text to the receiving end of the process. Translational bridges make it possible to convey a message across gulfs of potential misunderstandings, non-intellegibility, and chaos. The article shows that the bridge can be made in different ways and make use of different means. The more efficiently this bridge eases the passage of the message, however, the more easily additional meanings will slip over as well. Inoculation was a way of protecting people from a common and often fatal disease. The translations explored in the article show how it also involved issues of gender, religion, social position and ethnicity.
\end{abstract}

\footnotetext{
${ }^{1}$ University of Oslo, Oslo, Norway. ${ }^{凶}$ email: anne.eriksen@ikos.uio.no
} 


\section{Introduction}

The good Woman went to work; but so awkwardly by the shaking of her Hand, and but put the Child to so much torture with her blunt and rusty Needle, that I pitied his Cries, who had ever been of such Spirit and Courage, that hardly any Thing of Pain could make him cry before; and therefore Inoculated the other Arm with my own Instrument, and with so little Pain to him, that he did not in the least complain of it (Maitland, 1722:7).

T his account describes how a medical practice, common in the Middle East, was applied to a young English boy, the son of the British ambassador in Constantinople. It is written by the surgeon, Charles Maitland, who was present at the operation carried out by the local practitioner, an old Greek woman, and shows how a very concrete translation is taking place. Angered by the Greek woman's clumsiness and the pain she inflicted on the child, Maitland takes the operation into his own hands. By this move, the treatment is literally transferred from the blunt needle of the Greek woman to the British, male surgeon and his chirurgical lancet. The body of the young boy becomes a bridge of translation: one arm is treated by the Greek woman, the other by the British doctor.

The event was part of a larger story. In the early decades of the eighteenth century, smallpox inoculation was introduced into northern Europe from the Middle East. The method consisted of grafting or 'inoculating' infected matter from a person who suffered from smallpox into the arm of one who had not yet been attacked by the disease. This operation usually caused a mild case of illness, which then protected against further attacks. A series of translations and transformations was involved in the introduction of this new medical treatment. A vast literature exists on the introduction and effects of inoculation in Europe and the United States. Its focus has been on the organization and demographic implications of inoculation (e.g., Sköld, 1996; Brunton, 1992; Moseng, 2003), on the debates over the new method and its relation to Enlightenment philosophy (e.g., Darmon, 1989; Seth, 2008), on how inoculation as mass treatment reflected new ideas about population and probability (Foucault, 2009; Rusnock, 2002; Eriksen, 2010) and on the work toward global eradication of the smallpox disease (Razzell, 1977; Williams, 2010). The aim of the present article is to add to this research by a detailed investigation some core elements of the initial translational process: a close reading of the texts that first introduced a British reading public to the new treatment.

The major protagonists of this investigation will be Lady Mary Wortley Montagu, wife of the English ambassador to the Sublime Porte and mother of the boy above; the two physicians, Emanuele Timoni and Jacob Pylarini; and the surgeon Charles Maitland (Grant, 2019). The texts and practices of these four persons quickly became the hub of large and international debates over the use and usefulness of inoculation. These debates in their turn created a network of further translations (cf., e.g., Woodville, 1796; Seth, 2008; Miller, 1957; Williams, 2010; Eriksen, 2013). This article will nonetheless focus on the initial foursome. The translation they contributed to consisted of the transference of inoculation practice from its Middle Eastern context to a European medical one. An important part of this was the shift in linguistic code from a vernacular discourse into the learned Latin of the physicians and then back into new vernaculars, as the treatment became known in the West. As we shall see, however, far more complex translations and translational shifts also took place, affecting each other in what can be called intersectional entanglements. Inoculation was a medical practice, a way of protecting people from a specific, serious and a very common disease. In the early
European texts, it also became an issue of gender, religion, social position and ethnicity.

The present article starts from the general point that not only is translation (or indeed any type of communication) not a linear and simple process, but also that all the 'noise', 'muddle' and 'disturbances' that occur along the way are more than just that. Such additions to the original message are not only unavoidable, but parts of the message itself in its new and translated form. They may even represent what makes the message meaningful to its recipients (cf., e.g., Serres, 1980; Fiske, 1982 for the original of these perspectives). Translations transform and transfer. They produce new meanings and create new realities, because they are always embedded in social and cultural networks of their own time and place. They are stamped with the ambitions, understandings and goals of the translators, shaped by their agency and by the contexts in which the translations take place. More particularly, the article positions itself in the growing field of the history of translation in science (Dupré, 2018). In the early modern period, communication and translation of scientific knowledge were closely related to the Republic of Letters, understood here both as referring to the historical agents' understanding of themselves as a network, and to modern investigations of these networks (e.g., Grafton, 2009; Goodman, 1996). Within the Republic of Letters, translation can be understood metaphorically, as cultural translations (Burke and Hsia, 2007) or exchanges of knowledge, books and artifacts among agents who shared the use of Latin, but who lived in very different parts of the world. However, it also had important linguistic aspects, involving translations from one vernacular language to another, or from Latin into vernacular language. This was particularly important in the Enlightenment period. During the eighteenth century, vernacular languages, most notably English and French, came to challenge the position of Latin within the Republic, partly due to the increased number of women in the networks (Pal, 2012), but also caused by a growing wish to reach a larger general public outside the Republic itself. Within the Republic, the exchange of letters was an extremely important means of communication and dissemination of knowledge. Recent research points out that these letters ought to be understood as constitutive to the networks they were part of (Ogilvy, 2016). Entering into a correspondence network could be more or less formalized and obliging to the participants. This was not least important when a junior scholar or a scholar from the European periphery sought to be admitted among members of the Republic, who were more centrally placed, be it in terms of location, reputation or knowledge (Grafton, 2009). Writing letters in this context was no private affair, as they often were meant to be circulated and read aloud in the local network of the recipient. For this reason, the boundaries between letters and journal articles also were blurred, and it was quite usual for scientific and academic journals to print articles framed as letters. In many cases, these letters had first been read aloud in the Society, Academy or salon that published the journal (Goodman, 1996). The correspondences, and the networks that they were parts of, thus can be seen as networks of translation. They translated local knowledge from one part of the Republic or one region of the scientific world to another, not only making this knowledge available but also understandable. Moreover, letters in this period and contexts also translated between the (apparently) private sphere of friendship between corresponding individuals and the public sphere of the Society, journal and larger reading audience.

Within these networks of exchange, some agents took on-or were ascribed-the role as "go-betweens", brokers or translators. As pointed out by Raj (2016: p.41), this role could be formalized though the use of specific names or titles, as for instance the 
dragoman or translator in the Turkish context. Metcalf (2005) has suggested a three-stage hierarchy for the different types of gobetweens. The simplest type or form is the physical or biological, individual that quite corporeally carried material links between cultures or parts of the world (Metcalf, 2005: p.9). In the scene quoted at the start of the present article, the young boy obviously is this type of go-between. The second form is the transactional go-between, typically translators or traders who make possible the communication or exchange. The third and highest placed is the representational, found for instance in the work of priests, writers or artists. In actual fact, the three forms often are intertwined and will often be practiced by the same individual (Metcalf, 2005: p.10f). As the following investigations will show, it can be added that these forms also may be ascribed to agents, not only performed by them. As an example, the "good woman" in the initial quote is very much presented as a go-between of the simplest form, reduced to her shaking hands and the rusty needle. Another description of the same scene might have presented her as a transactional go-between, who makes the exchange of medical knowledge possible. In the text, this role is nonetheless reserved for the writer himself, who presents himself both as a transactional and a representational go-between.

From this more general understanding of the powers of translation and translational processes, the present article will develop the notion of translational bridges: to get the message through, the translator will have to make use of devices or arrangements that connect the source text to the receiving end of the process. Translational bridges make it possible to convey a message across gulfs of potential misunderstandings, nonintelligibility and chaos. As the study aims to show, the bridge can be made in different ways and make use of different means to do so. In the quote above, the body of the young boy supplies the image to serve this function. A common feature, however, is that the more efficiently the bridge eases the passage of the message, the more easily additional meanings will slip over as well. The inoculation of the boy describes a translation of a medical practice, but the image that is created also carries with it messages about gender and status, competence and skills, reliability and cleanliness.

The texts that are to be examined in the following are two treatises by Emanuel Timoni and Jacob Pylarini, both published in Philosophical Transactions, the journal of the Royal Society in London, in 1714. These texts are usually considered the first descriptions of Middle Eastern inoculation to reach a reading public in northern Europe. Lady Mary Montagu, who had her son inoculated in Constantinople in 1717, started propagating the treatment after her return to London in 1718. She did not lend her name to any published text about inoculation, but an anonymous text, in the London Flying Post in September 1722, has been discovered to be her work (Halsband, 1953: p.400 ff). She also wrote about inoculation in letters to her friends in England. The surgeon Charles Maitland, who assisted at the inoculation of Lady Mary's son and later inoculated her daughter, had his account of the method published in 1722 .

\section{A tale of two doctors}

The earliest texts represent the most literal type of translationfrom one language to another. In 1714, Philosophical Transactions published a text with the title 'An Account, or History, of the Procuring the Small Pox by Incision or Inoculation, as it has for some time been practiced at Constantinople'. A subtitle informed that the text was an extract from a letter by Emanuel Timonius, a medical doctor from Oxford and Padua, and a Fellow of the Royal Society. Another subtitle further informed that the letter, or rather the English extract from it, was communicated to the Society by its Fellow, the physician John Woodward. The communication took place at the society's meeting on 27 May (Poulako-Rebelakou and Lascaratos, 2003: p.181).

The role of Woodward, then, is varied. One the one hand, he is the humble translator of a Latin text into English. On the other hand, he is the original addressee of the letter from Constantinople, as well as the producer of its extract. And finally, he is the person who communicates this content to the Society at its meeting. In the terms of Metcalf (above) Woodward appears as both a transactional and a representational go-between. This blend shines through in the text, which starts as follows:

The writer of this ingenious Discourse observes, in the first place, that the Circassians, Georgians, and other Asiaticks, have introduced this Practice of procuring the Small-Pox by a sort of Inoculation, for about the space of forty Years, among the Turks and others at Constantinople. That also [...] This he attests upon his own Observation. (Phil. Trans. 1714-16, vol. 29. no 339, p.72, italics in original).

Introducing Timoni's letter by the use of indirect speech, Woodward situates himself as the author of the text, whereas Timoni himself, despite being the original source and authority of the information that is reported, becomes a third-person figure: 'He' or 'the writer'. At the same time, the phrasing establishes a certain distance between Timoni, who is making 'his own Observation' in faraway Constantinople, and Woodward, in his turn communicating the testimony to the Fellows of the Royal Society in London. This distance is retained until the end of the text, where the positions partly change and become more entangled. Woodward writes:

To this time, he says, I have known but one Boy, on whom the Operation was perform'd, and yet he had not the SmallPox, but without any mischief; and some Months after catching the common sort, he did very well, it is to be observ'd, that the places of the Incision did not swell. I suspect this child prevented the insertion of the Matter, for he struggled very much under the operation, and there wanted help to hold him still [...]. He goes on.

I have never observ'd any mischievous Accident from this Incision hitherto; although such Reports have been sometimes spread among the Vulgar (Phil. Trans. 1714, vol, 29, no 339 , p.75, italics original).

In these paragraphs, the word 'he' refers to two different figures: Timoni and the boy that was treated. The 'I' who appears for the first time in the text refers to Timoni himself. The character who reports on the events is thus allowed to merge with the one who has been making the observations. This access to the front stage of the text is nonetheless controlled by Woodward, who inserts the phrase 'He goes on', thus framing Timoni's ' $I$ ' in the context of his own translation. Timoni continues in the first person through the remaining pages of the English text, presenting one more case, as well as giving his own assessment of inoculation as a treatment. Then, Woodward's voice comes through again: “The rest of Dr. Timone's Letter contains his Reasons for this Method of Practice; which being the Aetiological Part, is publish'd in his own Words, as follows" (Phil. Trans. 1714, vol, 29, no 339, p.76, italics in original). The remaining pages are in Latin and signed 'Emanuel Timonius, Constantinopolitanus. In Universitatibus Oxoniensi \& Patavina Philosophiæ \& Medicinæ Doctor'. There is no doubt that the speaking subject of this part is Timoni himself.

Philosophical Transactions regularly published in both Latin and English. The partial translation of Timoni's text into English may indicate which portion of it Woodward wanted to reach a 
wider public. The linguistic shift draws a line between the useful knowledge about inoculation as a treatment in general and the medical theory that was of interest mostly to other physicians and learned men, who in their turn had no problems reading Latin. It can also indicate which parts of the letter Woodward actually presented orally-'communicated'-to the Royal Society at their meeting, and which remained a written document. It should however be noted that this shift and the distance created by Woodward's use of indirect speech also serves to split Timoni into two different figures, the 'he' and the 'I'. A related split can be seen in the rendering of his name. He is Timone in Woodward's English version, and Timonius in his own Latin signature. It was not unusual in this period that family names did not have standardized spellings. Shifting forms could represent the name in different languages, as is the case here. Moreover, the different spellings of Timoni's family name also signals ambivalence, making him oscillate between different positions, identities and types of authority, as well as between languages. So, who was he?

Emmanuel Timoni lived from 1669 to 1718 . He was the son of a dragoman at the Sultan's court in Constantinople, thus more or less born into the business of translation between the Ottoman and the European world. After studying medicine and philosophy at the universities of Oxford and Padua, Timoni became attached to the same court as a physician. In this capacity, he also rendered his services to the British embassies in Constantinople. The most common spelling of his name-Timoni-indicates Italian descent, but the original form was Timonis, a noble family of the Greek island, Chios (Poulako-Rebelakou and Lascaratos, 2003). In the Middle Eastern context, then, Timoni's name and career mirror the multi-lingual and multi-ethnic composition of the Ottoman Empire, as well as the cultural wealth of the Mediterranean region and the mobility of its elites. In the British context, however, he was a foreigner with a strange name. He wrote in Latin, he was a doctor, he had studied at Oxford, was a Fellow of the Royal Society and his alma mater, the university of Padua, was generally held in high esteem. His own understanding would have been that he was on a par with his friend Woodward, as well as with the other Fellows of the Society in London. As a translator, he saw himself in a representational role. From a European, or British, perspective, Timoni was not a suspect, but he was a stranger, an anomaly and an ambivalence. Was he Greek, Italian or Turkish? Did he belong to the Ottoman Empire or to the European world? Moreover, inoculation was a revolutionary and almost unheard-of method. Was the man who reported on this an empiric and a quack, or a learned physician doing scientific observations in a systematic way? Was he 'one of us' and, as such, granted the position of an enunciating 'I', or was he a stranger, a 'he' who required a mediating European voice to gain authority? Woodward's 'communication' to the Royal Society and to the reading public translated (parts of) Timoni's letter from one language to another, but at the same time created this very ambiguous figure, ascribing Timoni the role of a transactional go-between, perhaps even giving him the task of a mere material communication of exotic medicine. It also situated Woodward himself as the more important translator, on whose authority and competence Timoni and the Fellows of the Society all were dependent for the information to come through.

The same volume of Philosophical Transactions (vol 29, 1714-6) also contains another text on inoculation. It has the title 'Nova \& tuta Variolas exitandi per Transplantationem Methodus, nuper inventa $\&$ in usum tracta'. The author, also according to the title, was Jacobus Pylarinus, 'M. D. \& Reipublicae Venetae apud Smyrnenses nuper Consulem'. No part of this text was translated into English and there is no information about its being communicated to the Fellows of the Society in any way other than print. Its author, Pylarini (1659-1718) had practiced inoculation in Constantinople since the epidemic of 1701 and thus had a thorough experience with the method (Poulako-Rebelakou and Lascaratos, 2003: p.181). Similar to Timoni, he gained his medical degree from the University of Padua, where he also read jurisprudence. A well-travelled person, Pylarini had practiced as a physician in a number of European and Middle Eastern countries, and held the appointment of physician to the Russian tsar. As a diplomat, he had been in the service of the Venetian Republic. He wrote his Latin treatise on inoculation on the request of his friend William Sherard, the British consul in Smyrna, who in his turn had received a list of questions from the secretary of the Royal Society, Richard Waller. Pylarini also published his treatise as a separate edition in Venice in 1715.

Similarities between the texts in Philosophical Transactions have suggested a collaboration between the two men, but also allow for the possibility that Timoni, who was the younger and less experienced of the two, had gained his knowledge from Pylarini (Poulako-Rebelakou and Lascaratos, 2003; Grant, 2019: p.74f). In the present context, it is equally relevant that the similarities between the two texts, as well as the connection between their authors, were significantly enhanced in the European context. Similar to Timoni, Pylarini also had his name rendered in different languages, ascribing him different identities. $\mathrm{He}$ is called Pylarino, Pylarinus and Pilarino, and the spelling of his Christian name varies between Giacomo, James, Jacob, Jacobus and Jacovo. A native of the Ionian island, Cephalonia, which at that time belonged to the domain of the Venetian republic, he is referred to as an Italian, a Venetian and a Greek. The ambivalence that has already been discussed related to Timoni and thus also holds true for Pylarini. This is overshadowed by the fact that his treatise was presented in a more unmediated way and on its own premise, and was also published as an independent work in Venice. To readers in northern Europe, the two men came to share the same kind of foreignness and ambiguity.

This development started with Philosophical Transactions publishing their texts in the same volume and with the latter (Pylarini) cross-referenced to the first. It was further strengthened when the two texts were published jointly in Frankfurt am Main in 1721, after both authors' deaths. In this volume, Timoni's text was entirely in Latin, thus corresponding linguistically with that of Pylarini. As the third person and indirect speech of Woodward's English translation is kept up, the Latin version does not seem to be Timoni's own original, but yet another translation.

When an abridged edition of Philosophical Transactions was published by the Royal Society in 1809 , both texts appeared in English. The indirect speech and the shifts between first and third person in Timoni's text are maintained, and the same feature can now be found in that of Pylarini, translated for the first time. Pylarini likewise becomes 'he', 'the author' and 'Dr. P' in his own text. Furthermore, some paragraphs from his original treatise have been excluded. Most notably, this concerns his remarks about the dubious remedies of quack and empirics, contrasted with the advantages of inoculation. Timoni's aetiology of the smallpox disease, which was rendered in Latin in 1714, is very briefly summarized in English in the new version, but "respecting a theory now universally exploded, it cannot be necessary to enter into further details" (Philosophical Transactions vol. 29, abridged version 1809, p.91). As vaccination had taken over for inoculation by the turn of the century, inoculation had become a nearly obsolete method. The two articles were mostly of historical interest and their basic medical theory discredited. In consequence, the translations have purged both texts of passages that appeared outdated and at the same time removing elements that were particular to the author of each. In the new edition, both texts also are supplied with notes of historical and biographic information. In these notes, the two authors are most often 
mentioned together and even if the intention may have been to discuss the possible connections between them, the result is to emphasize the presumed bonds. Lumped together in this way, the two authors are pushed further towards the lower forms of the hierarchy of go-betweens. Their powers of (correct) representation are not recognized and the lines between themselves as doctors and the local quacks are deleted.

\section{Creating credibility}

So far, the writings by Timoni and Pylarini have been examined as source texts in translational processes. However, these texts also represent acts of translation and transference in their own right. As neither of the two physicians probably spoke Latin with their patients in Constantinople, translations from the vernacular to an erudite language must have taken place. A corollary to this is also the transference from practice to text, which is to be explored here. According to their wording, each text is written on the basis of the respective authors' personal observations and experience. Even if this directness becomes somewhat diluted in translation, their role as eyewitnesses has been important both to the two physicians themselves and to the journal editors. It is nonetheless expressed by different means in the texts.

In Timoni's text, both the practitioners and the patients of inoculation are referred to as 'they'. Only in the latter parts of the text do specific persons appear as "in a certain family, a Boy of 3 Years old" and "in another Family, a girl of 3 Years old" (Phil. Trans., 1714, vol, 29, no 339, p.75f, italics original). These cases are parts of Timoni's discussion of potential risks and dangers related to inoculation, which implies that they are exceptions. The argument is that the fatal outcome of these particular cases was due to other pre-existing medical conditions in the patients. The regular cases, on the other hand, which Timoni claims to have direct knowledge about, are presented in very general terms. The operation has "been perform'd on Persons of all Ages, Sexes, and different Temperaments, and even in the worst Constitution of the Air" (Phil. Trans., 1714, vol., 29, no. 339, p.72). After inoculation has been carried out, Timoni also states, the illness begins "to appear sooner in some than in other, in some in greater, in others with lesser symptoms" (Phil. Trans., 1714, vol., 29 , no. 339, p.74). The numerous but anonymous patients as well as the impersonal 'some' in these paragraphs are vital to produce a description of what usually happens and of what has happened often enough for it to make the basis for general assumptions about how inoculation works. The plural form 'they' is also used about the practitioners, giving the impression of a considerable number of inoculators at work. However, this phrasing also creates a distance to the events that are reported and to the author's own part in them. It means the personal observations remain no more than a claim, and that the details and particularities, which they would have been expected to produce, are sacrificed to the statement of general rules.

Pylarini's text differs from this on significant points. It starts by declaring that inoculation is "Operationem Medicam inventu non minus quam eventu mirandam Orbi literario pandimus; Non a Phyfica cultoribus, aut adoctis in Apollinea arte viris, sed a plebea rudique gente in humani generis adjumentum ..." (Phil. Trans., 1714, vol. 347, p.393). ${ }^{1}$ The name of the inventor remains unknown, Pylarini says, and in Constantinople, only a small number among "the lower orders of people" used to practice it. During the winter of 1701 , however, these matters changed due a ravaging epidemic. Pylarini tells how he was summoned by a friend, a Greek nobleman with three sons, and was asked for advice. Would Pylarini recommend inoculation to save the boys from the epidemic?
This is where the discrepancy between the Latin original and the English translation occurs, Pylarini being the 'I' and the 'he' of the respective text. In both versions, however, the account remains detailed and specific. Pylarini refers explicitly to the situation in his friend's family, his own uncertainty, and how "a person who was experienced in the matter" was invited to the house. Three days later, when Pylarini again visited his friend, there was shown into the room a Greek woman who explained the process of inoculation to the two men. She referred to a large number of cases to prove the safety of the method and Pylarini adds that as far as he had been able to check, what she said about them was true. The two men were convinced and the young boys were inoculated by the woman. It all went well and several noble families in the area then followed example. Pylarini's text goes on to explain how the inoculation was carried out in the case of the three boys and ends with some more general remarks organized in four "points to be noted".

The prominent figure of this account is the Greek woman. It is her actions that are reported, as well as her choices and recommendations. By means of the introduction, this presentation is nonetheless framed in a way to give Pylarini an important position. It is his advice that his friend, the nobleman, originally asks for, and in whose house Pylarini is a frequent and apparently highly respected guest. It is also he that checks the veracity of the Greek woman's account of former cases. His description of the operation itself is detailed and precise:

Fourthly, when she entered the room upon the operation, she punctured the middle and upper part of the forehead, the chin and both cheeks, with a needle. The puncture was made not perpendicularly, but obliquely, the cutis being separated a little with the sharp point of the instrument, from the subjacent flesh. She then introduced into the wound the pus contained in the small vessel beforementioned; and afterwards tied on a bandage. She made similar punctures in the back of the hands, and on the feet, strictly cautioning the patient against scratching or wetting the inoculated places (Phil. Trans. vol. 29, ed. 1809, p.209).

This is obviously written by an eye witness, but also by a skilled physician, who, for instance, is able to note exactly how the insertion was made. At the end of the passage, Pylarini adds he himself would have chosen the more fleshy parts of the body for the operation, as this would reduce the risk of infection. He offers his judgement in similar ways in other parts of the description. The rendering of the procedure in numbered points, of which the actual insertion is the fourth, also signals that this is not the testimony a random onlooker, but the work of a person trained to refer to 'scientific data' in systematic and precise ways. Although Timoni worked to achieve authority by transforming his observations into general rules, independent of specific agents and situations, Pylarini's authority on inoculation is created by the opposite means: specific details and a strong personal presence in the reported events.

\section{Gendered trouble}

Although the reception of their texts construed Timoni and Pylarini as foreigners, these texts in their turn had had to deal with the foreignness of the treatment that was presented. The two short treatises translated the practice into words, but they also seek to translate a treatment that appeared exotic, strange and even dangerous, into something that was understandable and hopefully acceptable to a public in northern Europe. In Pylarini's text, this act of transference is carried out by a strategy of paradoxes and oppositions. 
The inoculator that Pylarini introduces to his readers is an anonymous Greek woman. She is presented as truthful and skilled, and, more implicitly, as honourable. She is, however, not a learned physician, but appears rather as a representative of the anonymous inventors of inoculation, 'a vulgar, illiterate people', who nonetheless have created a treatment that is a blessing to the entire human race. Pylarini emphatically sets this paradoxical figure against the usual quacks who take advantage of popular superstition. To this is added another significant contrast. Pylarini's work of translation is modelled on the fundamental contrast between himself as the learned, respected, European, male physician, and the nameless inoculator who is a stranger, probably illiterate, somewhat obscure and-crowning it all-a woman! Mellemgaard (1998) and French (2003) both have pointed out that an insistence on such contrasts traditionally was part of the conscious selffashioning of physicians. In actual fact, learned doctors had little to offer their patients that was substantially different from vernacular medicine. As men of science and in defence of their social position, physicians nonetheless sought to create an image of their profession, knowledge and work that differed significantly from the practice of vernacular healers and empirics. It is this well-known construction that Pylarini sets into play in his text. What makes possible the translation between the two apparently different worlds is the bridge that Pylarini constructs: he emphasizes that the woman is no mere quack, like those known from the northern parts of Europe. She is proven to tell the truth about her cases. The operation she carries out is of a kind that Pylarini easily can describe in the language of his own profession. Moreover, her actions and recommendations can be rationally commented on, as Pylarini probably might discuss and comment on the professional choices of other colleagues.

Timoni's strategy for translation differed strongly from this very active use of contrasts and oppositions. His preference for generalizing statements, even when they undermined the claim that his account was based on personal experience, reflect other principles. It represents a way of cleansing the material of the foreignness of both method and agent. The favoured pronoun 'they' creates a generalized Other, whereas at the same time effacing gender. Timoni was hardly ignorant of the fact that the inoculators in Constantinople were female, but his choice of terms effectively hides this. 'They' are ungendered. Timoni builds his bridge of translation by describing inoculation as much as possible in general terms, making it comparable to any other medical treatment and by cleansing out particularities that bespeak its exotic origins-among them the gender of the practitioners.

Gender nonetheless remained an aspect of the translation processes, not least due to one of the main figures in this story. When Lady Mary Wortley Montagu arrived in Constantinople in 1716 with her husband and young son, she had recently survived a severe attack of smallpox. Some years earlier, her only brother had died from the same disease. Consequently, when an epidemic raged in 1717, Lady Mary set to work to save her son. The embassy surgeon, Charles Maitland, was summoned. According to his own account, published in 1722, the first task he was given by Lady Mary was to find a person already attacked by smallpox, from whose pustules the infected matter could be taken. Lady Mary then "sent for an old Greek Woman, who had practis'd this Way a great many Years” (Maitland, 1722: p.7, italics original). When the 'good Woman' went to work, however, things did not go too well, according to Maitland, whose description of the operation was quoted in the introduction to this article. According to his own account, he vigorously took the operation in his own hands, and is able to present his reader with a vivid image of a corporeal bridge of translation created by the forceful intervention.

Back in London the year after, Lady Mary also wanted her young daughter to be inoculated. Maitland was again summoned and carried out the operation, which he describes with selfsufficient expertise. He ends this description by saying that he knows a "great many cases" of inoculation from Turkey, and none that have not succeeded. The operation itself, he tells his readers, is... indeed simple and obvious, and may, like other plain Chirurgical Operations, be in a manner Mechanically learn'd and practis'd: For, not to mention several surgeons, whose Business it is, I knew an old Greek Woman, who, having been taught from her Youth, had practiced it with Success a great many Years (Maitland, 1722: p.12).

In this passage the translation and transformation are complete. The treatment is no longer strange and foreign, but an operation within the professional scope of any surgeon or person who has been trained in this simple mechanical art. It can even be done by old Greek women. The expertise has shifted and the female inoculators in the Middle East no longer appear as the source of knowledge and skill but have been transformed into proof of the extreme simplicity of the operation.

In the process of transferring inoculation from the Middle East to northern Europe, the 'old Greek woman' was obviously an important figure. The testimonies that are examined here demonstrate that this not only concerns the practice as such, but that this figure also serves as a pivot in the translational processes within the texts. Transferring inoculation to the context of European learned medicine meant domesticating its profound foreignness. On the one hand, the female practitioner was the ultimate expression of this foreignness, but on the other she also came to serve as a very potent translational tool, employed in various ways by the different authors.

In the quotes from Maitland's text (above), this figure appears in two different roles. In the first case, she is old, clumsy, shaking, and probably dirty - at least the needle that she uses has been allowed to rust. In the second, she has inoculated successfully for years, even if her age is not stressed. The success, however, is not due to her particular skills but to the simplicity of the method. It is not possible to ascertain whether Maitland had met several female inoculators in Constantinople or whether he has adjusted his description of one single person to its function in the two different parts of his own account. More important is it, that taken as a whole, the two contrasting portrayals serve to enhance the coherence of Maitland's presentation. They help him to tell the story of how inoculation was taken out of the hands of its somewhat dubious local practitioners, only to reappear as a practice "indeed simple and obvious", available even to persons with absolutely no medical learning as long as they have been taught some basic skills.

Maitland's professional self-assurance notwithstanding, the inoculations that he describes took place on Lady Mary's initiative, and according to her wishes. It was she who summoned the surgeon and set him to work, and she who found the inoculator that Maitland met in her house. She acted as a mother who wanted to protect her children, but also as a resourceful cultural entrepreneur, approaching people and practices that were generally unknown to her compatriots in Constantinople or in London. In a letter to a friend in London, she appears as a field-working ethnographer, describing the customs that she has observed:

There is a set of old women who make it their business to perform the operation every autumn, in the month of September, when the great heat is abated. People send to one another to know if any of their family has a mind to have the small-pox: they make parties for this purpose, and 
when they are met (commonly fifteen or sixteen together), the old woman comes with a nut-shell full of the matter of the best sort of small-pox, and asks what vein you please to have opened. She immediately rips open that you offer to her with a large needle (which gives you no more pain than a common scratch), and puts into the vein as much matter as can lye upon the head of her needle, and after that binds up the little wound with a hollow bit of shell; and in this manner opens four or five veins (Lord Wharncliffe, 1837: p.394).

Whereas the Greek woman appears rather suddenly, as if from nowhere, in the texts that have been examined so far, Lady Mary presents the inoculators in their original social setting in Constantinople. She also emphatically describes a regular practice, something that takes place in the same way and at the same time every year. This approach reduces the foreignness of the practice and the abruptness of its agents' appearance in the text. What happens is regular, safe and even pleasurable: it is a party and, after being treated, the children play together for the rest of the day. By referring to them as a 'set', Lady Mary also turns the inoculators from eccentric individuals to performers of a certain set of skills.

Lady Mary's letter was not made public until much later. Back home in England, she worked hard to introduce inoculation. Published texts and public debate were not the means of a woman of high nobility, but social position, connections and friendship came in useful. It was at the instigation of Lady Mary that the princess of Wales, wife of the future George II, had her children inoculated. In 1722, the London Flying Post did however publish "An Account of the inoculating the small pox at Constantinople, by a Turkey Merchant". The merchant was Lady Mary in disguise, and what made her write was anger. The original manuscript, found and investigated by Richard Halsband, has passages of raw sarcasm. The elegant wit, so distinctive to Lady Mary's own literary works, has been dispensed with and strong indignation dominates. The description of inoculation practice in the Middle East in this account is more or less identical with what Lady Mary had already written in her private letters (quoted above). The inoculator is termed 'the nurse', or just 'she', once again signalling the presence of the 'Greek woman'. What has ignited the merchant's anger, however, was the translation of this simple practice made by English physicians. The aim of the account was to warn, "out of compassion to the numbers abused and deluded by the knavery and ignorance of physicians" (Halsband, 1953: p.401).

According to European medical theory, purging (blood lettings and laxations) and strict dietary regimes were regular elements of any treatment or cure. Such 'preparations', which might take as long as a couple of weeks, also became part of inoculation in Europe (Eriksen, 2013). The indignant merchant referred to the 'murders' committed by 'our learned physicians' due to this method: "their long preparations only serve to destroy the strength of the body necessary to throw off the infection" (Halsband, 1953: p.402). The inoculation itself was no longer a simple prick of a needle, but consisted of the "miserable gashes that they give people in their arms", "the vast quantity they throw in of that infectious matter" and "the cordials that they pour down their throats" (Halsband, 1953: p.402). Strong fever, dangerous infections and the risk of 'the worst kind of small pox' regularly followed from these procedures, the merchant claimed. Inserted into the context of European, learned medicine, inoculation had become complicated, inaccessible and dangerous. It had not been properly understood, according to the merchant: the translation that had been made was false and had fatal implications.
Halsband has shown how the editor of the Flying Post moderated several of the most aggressive expressions. 'Murder' was changed to 'misfortune' (Halsband, 1953: p.401, note k). Hints that the mistranslations had been made intentionally and for mercenary reasons, were deleted. What the editor did not moderate, however, was a fundamental aspect of the text: Lady Mary's radical self-translation. Disguising herself as a Turkey merchant she concealed her gender as well as her nobility and position in English society. The personae hid her true identity and turned the author into a stranger, at the same time increasing the authenticity of the report. The authorial voice came to express a male world of active life and rational knowledge. The author moreover appeared as a true spokesman of that part of the world, where inoculation was practiced as a safe and regular treatment. Casting herself as an outsider to the English society in which her real self was so nobly placed, Lady Mary could appear as a true and trustworthy witness to Middle Eastern practice, hindered neither by her social position nor by her gender.

\section{The Turks?}

Inoculation was practiced in Constantinople, but by whom? Who were the people who used to send for the 'Greek woman' in the autumn, as Lady Mary described, and have regular inoculation parties? According to Timoni (above), "Circassians, Georgians, and other Asiaticks," had brought inoculation to the Turks and others in Constantinople. A similar account can be found in Maitland:

A Method, new indeed, and utterly unknown here, till of late, tho' universally practis'd with Success all over Turky these threescore Years past; and in other Parts of the East, a hundred, or, for ought we know, some hundreds of Years before (Maitland, 1722: p.2)

According to these authors, Turks in Constantinople are obviously not the inventors of inoculation, but have lately been introduced to it by Circassians and Georgians. These groups, mainly living in Caucasus, were important minority groups in the large empire and, in this period, largely Christian. The transference to the "Turks" at Constantinople thus seems not only to imply the crossing of space but also of religious borders. The 'other Asiatics' lessens the precision of Timoni's statement and makes the presumed process of distribution difficult to grasp. Maitland, for his part, is even more vague about its place and people of origin. What both authors communicate, however, is that the practice is old, that its precise origin within 'Turkey' is unknown, and that it for some decades now has been used by 'Turks' in Constantinople. The effect of this is somewhat paradoxical. Even if Turkey is not the only land mentioned (or implied) and the Turks (in Constantinople or elsewhere) are certainly not cited as its inventors, both texts contribute to pin down inoculation as 'Turkish' simply by their frequent use of the term and their correspondingly vague references to other groups and places.

Alicia Grant has pointed out that 'Turkey' and 'Turks' in this period worked both as general designations of the Ottoman Empire and its inhabitants, and, at same time, as a term for 'Muslim' (Grant, 2019: p.67). The empire was a conglomerate of languages, ethnic groups and religions, living side by side in comparative liberty (Grant, 2019: p.68). The terms thus worked as easy shorthand for a great multitude. Not least was it a means of simplification useful to confused visitors from the north who were trying to cope with the general 'foreignness' that they encountered in Constantinople and other parts of the empire. Timoni was a native to this diversity and even Maitland had stayed in Constantinople long enough not to be a stranger to it. However, 
despite their knowledge about the multiplicity of regions, people and religions within the empire, they did not escape the simplification inherent in the terms that they made use of. Nor did they avoid the fact that 'Turkish' was so easily translated as 'Muslim'.

In the public debate after the first inoculations in London, the new treatment was denounced as un-English and harmful. According to the physician William Wagstaffe, it was a method totally strange to English constitutions, imported from "an illiterate and unthinking People", living in a warm climate, but "on a spare Diet, and in the lowest manner, almost without the common Necessaries of Life" (Wagstaffe, 1722: p.6). The Reverend Edmund Massey denounced inoculation as un-Christian. Only to individuals of a superstitious and fatalist religion, inoculation may appear reasonable, he argued:

Indeed where the Doctrines of Salvation are not known, and a regular Dependence upon Providence is postponed to the absurd belief of a Fatality; there it is no wonder to see Men give into impious or unreasonable Practices (Massey, 1722: p.15f).

Christians, for their part, "cannot easily be reconciled to a Practice, which abuses their Understanding, as well as insults their Religion" (Massey, 1722: p.16, italics original).

The arguments presented by Wagstaffe and Massey consolidated an understanding of inoculation as "Muslim" in the ensuing debate in northern Europe. Grant argues that this was a serious misconception-or, in the terminology of the present article-a mistranslation. Inoculation was not a Muslim practice. The different ethnic and religious groups within the empire lived quite separately, she points out, with little contact and little knowledge about each other. Inoculation would probably not cross religious or ethnic borders, even among people living in the same city. She also argues that the Montagu family, similar to other foreign envoys, lived in a part of the city that was almost exclusively Christian, even if different ethnicities were represented. Lady Mary's knowledge of Muslim neighbourhoods and practices was probably rather limited. What she and the other writers cited here knew about inoculation in the empire, came from the Christian groups (Grant, 2019: p.70f).

Grant also refers to Pylarini's statement "The Turks alone, so addicted are they to their predestinarian notions, and so rivetted to ancient prejudices, neglect to reap any advantage from it" (Phil. Trans., vol. 29, ed. 1809, p.208). A similar phrase can be found in Maitland's text, as part of his work to counter the objections from Wagstaffe and Massey:... nobody pretends to give us an Instance of an Inoculated Turk. And why? Because their Belief of a Fatality makes them neglect very much the ordinary Helps of Medicine for preserving their Lives (Maitland, 1722: p.42).

In these statements, Turk obviously means Muslim. The argument is that religious faith makes them refuse inoculation. Pylarini's description of how it was introduced in Constantinople corroborates this. It is more nuanced than those of Timoni and Maitland. Inoculation was first practiced in Greece, and above all in Thessalonica, according to Pylarini. Only slowly did it spread, and when it finally reached Constantinople, only "a few persons, among the lower orders of people, now and then made trial of it" (Phil. Trans., vol. 29, ed. 1809, p.207).

Considering Pylarini's general level of precision, his account seems credible, as does also his information about which groups were practicing it. Despite the more accurate knowledge, the generalizing statement about Turkish fatalism or "predestinarian notions" is nonetheless as Orientalist as the phrases of the two others and situates Muslims in the position as "Others" or strangers. It stamps Islam as a religion that is irrational and superstitious, and Muslims as inferior to Christians, intellectually and religiously. They are deceived and subdued by a religion that forbids them to take action to save their own lives. Somewhat paradoxically, Reverend Massey's main anti-inoculation argument was that man had not the right to inflict illness on others or to decide in questions of life and death. Christians should know that God alone was entitled to this, and that illness was a divine chastisement (Massey, 1722). The point here is not to decide which religion has the greatest faith in divine authority, but to show that when the shorthand term 'Turk' translated as 'Muslim', the result was not merely an incorrect identification of the users of inoculation. It also added new dimensions to the conceived alienism of the method.

\section{The bridges of translation}

The aim of this investigation has not been to point to inaccuracies or errors in the translations of texts or practice, and even less to suggest intended deceptions. What the examinations of the texts have shown, however, is the capacity-and even necessity-of translations always to create something new, intended or not. Translations are meant to make the translated contents available to new readers. In the case of inoculation, the urgency of this was very explicit. The task that the four authors, whose texts have been examined here, had all set themselves, was to make this lifesaving method known and available outside the Ottoman Empire. Their texts were a means to this end. The same shines through in Woodward's translation of (parts of) Timoni's Latin text into English. At the same time, his work clearly illustrates the transformative character of translation. His small additions and adjustments added new aspects to the original discourse. From a formal standpoint, this may seem like a distortion. From a more functional perspective, it was a means to enhance translational success. Doing so, Woodward created the bridge, across which translation could take place and the foreignness of the author and his message could reach the readers. The other agents created their bridges in other ways and by other means. In Maitland, the bridge consisted of the body of the inoculated boy. Timoni's generalizations, Pylarini's use of contrasts and paradoxes, and Lady Mary's transgendered performance are also all such bridges of translation, created by the authors to make their task feasible, but at the same time adding new dimensions and new elements. The success and efficacy of the various strategies may be questioned, but in the present context, it is the very necessity of such bridging devices that is the point, as well as their vital importance to the translational processes.

The bridges are built to make the message come across. However, the material from which they are built also makes it possible for other, and additional meanings to slip through. The most obvious example is the way the imprecise terms 'Turk' and 'Turkey' brought with them the meaning 'Muslim', which then activated chains of equivalence translating medical practice into religious peril. The gender issue is another such element. Although Timoni sought to conceal the gender of the inoculators in Constantinople using impersonal and generalized terms, Pylarini made use of it as a resource in building up his paradoxes. The background for both strategies, however, are the social and cultural meanings that (female) gender carries with it, and again the chains of equivalence it activates. Without anything else being known about them, their training, competence or social position, the female inoculators inescapably appear as paradoxical figures. Their gender alone turned them into representatives of lay knowledge, folk customs, uncleanliness and ignorance, trickling further into clumsiness, superstition, irrationality and potential peril.

Translations are interventions that generate meaning by making an original message cross a bridge that has been built for 
the purpose, but in doing so they activate other discursive fields, and set unexpected chains of equivalence into play, making them part of the matter. Crossing the bridge infuses the message with other meanings, which in their turn trickle off into other fields. Inoculation was a medical practice, a way of protecting people from a specific, serious and very common disease. By means of the translations that have been examined here, it also became an issue of gender, religion, social position and ethnicity.

\section{Data availability}

The data for the article consists of published, historical documents (journal articles), listed under the references.

Received: 19 November 2019; Accepted: 5 March 2020;

Published online: 24 March 2020

\section{Note}

1 For an English translation, see Phil. Trans., vol. 29, ed. 1809, p.207

\section{References}

Burke P, Hsia RPo-chia (2007) Cultural Translation in Early Modern Europe. Cambridge University Press, Cambridge

Brunton D (1992) Smallpox inoculation and demographic trends in eighteenthcentury Scotland. Med Hist 36:403-429

Darmon P (1989) La variole, les nobles et les princes: La petite vérole mortelle de Louis XV. Complexe, Bruxelles

Dupré S (2018) Introduction: science and practices of translation. Isis 109 (2):302-307

Eriksen A (2010) A case of exemplarity: C.F. Rottböll's history of smallpox inoculation in Denmark-Norway, 1766. Scand J Hist 35:351-370

Eriksen A (2013) Cure or protection? The meaning of smallpox inoculation, ca 1750-1775. Med Hist 57(4):516-536

French R (2003) Medicine before science. Cambridge Univ. Press, Cambridge

Fiske J (1982) Introduction to communication studies. Methuen, London

Foucault M (2009) Security, territory, population: lectures at the Collège de France 1977-1978. Picador, New York

Goodman D (1996) The republic of letters. A cultural history of the French enlightenment. Cornell Univ. Press, Ithaca

Grafton A (2009) Worlds made by words. Scholarship and community in the modern west. Harvard Univ. Press, Harvard

Grant A (2019) Globalisation of variolation. The overlooked origins of immunity for sSmallpox in the 18th century. World Scientific, New Jersey

Halsband R (1953) New light on Lady Mary Wortley Montagu's contribution to inoculation. J Hist Med Allied Sci 8:390-405

Maitland C (1722) Mr. Maitland's account of inoculating the small pox. J. Downing, London

Massey E (1722) A sermon against the dangerous and sinful practice of inoculation. W. Maedews, London

Mellemgaard S (1998) Kroppens natur. Sundhedsopplysning og naturidealer i 250 år. Museum Tusculanum Press, København

Metcalf AC (2005) Go-betweens and the colonization of Brazil, 1500-1600. University of Texas Press, Austin

Miller G (1957) The adoption of inoculation for smallpox in England and France. University of Pennsylvania Press, Philadelphia

Moseng OG (2003) Ansvaret for undersåttenes helse 1603-1850. Universitetsforlaget, Oslo
Ogilvy B (2016) Corresponding networks. In: Lightman B (ed.) A companion to the history of science. Wiley, Blackwell, Hoboken, p 258-271

Pal C (2012) The republic of women. Rethinking the republic of letters in the seventeenth century. Cambridge Univ. Press, Cambridge

Poulako-Rebelakou E, Lascaratos J (2003) Emmanuel Timonius, Jacobus Pylarinus and inoculation. J Med Biogr 11:181-182

Pylarini J (1714) "Nova \& Tuta Variolas Excitandi per Transplantationem Methodus, Nuper Inventa \& in Usum Tracta... " [A New and Safe Method of Communicating Smallpox ...]. Philos Trans 29:207-210. 16

Raj K (2016) Go-betweens, travelers, and cultural translators. In: Lightman B (ed.) A companion to the history of science. Wiley, Blackwell, Hoboken, p 39-57

Razzell P (1977) The conquest of smallpox: the impact of inoculation on smallpox mortality in eighteenth century Britain. Caliban Books, Firle

Rusnock AA (2002) Vital accounts: quantifying health and population in eighteenth-century England and France. Cambridge Univ., Cambridge

Serres M (1980) The Parasite. Johns Hopkins Univ. Press, Baltimore

Seth C (2008) Les rois aussi en mouraient: Les Lumières en lutte contre la petite vérole. Éditions Desjonquères, Paris

Sköld P (1996) The two faces of smallpox: a disease and its prevention in eighteenth-and nineteenth century Sweden. Umeå Universitet, Umeå

Timoni E (1714) An account of the history of the procuring of small pox by incision or inoculation. Philos Trans 29:88-91. 16

Wagstaffe W (1722) A letter to Dr. Freind, Shewing the Danger and uncertainty of inoculating the small pox. S. Butler, London

Williams G (2010) Angel of death: the story of smallpox. Palgrave Macmillan, Basingstoke

Wharncliffe L (1837) The letters and works Lady Mary Wortley Montagu, vol. 1. Richard Bentley, London

Woodville W (1796) The history of the inoculation of the small-pox in Great Britain. J. Phillips, London

\section{Acknowledgements}

None.

\section{Competing interests}

The author declares no competing interests.

\section{Additional information}

Correspondence and requests for materials should be addressed to A.E

Reprints and permission information is available at http://www.nature.com/reprints

Publisher's note Springer Nature remains neutral with regard to jurisdictional claims in published maps and institutional affiliations.

\begin{abstract}
Open Access This article is licensed under a Creative Commons Attribution 4.0 International License, which permits use, sharing,
adaptation, distribution and reproduction in any medium or format, as long as you give appropriate credit to the original author(s) and the source, provide a link to the Creative Commons license, and indicate if changes were made. The images or other third party material in this article are included in the article's Creative Commons license, unless indicated otherwise in a credit line to the material. If material is not included in the article's Creative Commons license and your intended use is not permitted by statutory regulation or exceeds the permitted use, you will need to obtain permission directly from the copyright holder. To view a copy of this license, visit http://creativecommons.org/ licenses/by/4.0/.
\end{abstract}

(C) The Author(s) 2020 